\title{
EDITORIAL ACKNOWLEDGEMENT
}

The Editor and Editorial Board wish gratefully to acknowledge the contribution of the following individuals who have assisted in the publication of the Journal through 1979 by their thorough review of manuscripts.
Dr. Douglas Blenkarn
Dr. Beverley Britt
Dr. William Brummitt
Dr. A. Charles Bryan
Dr. A.F. Clanachan
Dr. James Duffin
Dr. Alison Froese
Dr. Werner Kalow
Dr. Koger Maltby
Dr. J.W.R. McIntyre
Dr. David Mitchell
Dr. Mary Morris

\author{
Dr. H.J.A. Nisbet \\ Dr. Paul Otton \\ Dr. R.J. Palahniuk \\ Dr. J.R.A. Rigg \\ Dr. Jose Rosales \\ Dr. Philip Seeman \\ Dr. I.A.J. Sloan \\ Dr. J.M. Smith \\ Dr. W.E. Spoerel \\ Dr. J.P. Tetrault \\ Dr. Davy Trop
}

We also express our grateful appreciation to Dr Yves Lamarche for translations.

\section{CORRECTION}

SMOKING AND GASTRIC JUICE VOLUME IN OUTPATIENTS

D.J. Wright and A. Pandya

Canadian Anaesth. Soc. J. 26: 328 (July 1979).

The address of Dr. A. Pandya is Department of Anaesthesia, Memorial University, St. John's, Newfoundland. The study reported in this paper was done at Me morial University. 